\title{
Pengembangan Media Tongkat Ajaib Tema Peduli Terhadap Makhluk Hidup
}

\author{
Aditya Fauzul Muna*1, Henry Januar S.2 , Muhajir³ \\ ${ }^{123}$ Pendidikan Guru Sekolah Dasar, Fakultas Ilmu Pendidikan, Universitas PGRI Semarang
}

\begin{abstract}
Abstrak
Tujuan penelitian ini adalah untuk mengetahui kepraktisan dan kevalidan media Tongkat Ajaib yang digunakan untuk siswa kelas IV sekolah dasar. Jenis Penelian ini adalah penelitian dan pengembangan atau Research and Development (R\&D) yang dikemukakan Sugiyono dengan menggunakan prosedur pengembangan Keywords:

Pengembangan, media Tongkat Ajaib, pembelajaran Talking Stick sampai tahap ketujuh yaitu merevisi produk. Peneliti memodifikasi langkah pengembangan menjadi beberapa tahapan yaitu potensi dan masalah, pengumpulan informasi, desain produk, validasi desain, perbaikan desain, uji coba produk, revisi produk (jika ada), dan produk siap. Penelitian ini dilaksanakan pada 3 sekolah yaitu ; di SD Negeri 2 Pelemkerep, SD Negeri 1 Mayong Lor, dan di SDIT Alhusna Pelemkerep. Peneliti mengembangkan media tongkat ajaib dengan hasil uji kevalidan diperoleh berdasarkan penilaian ahli media, ahli materi, dan ahli soal materi dengan skor rata-rata dari ahli media sebesar $99 \%$ dengan kategori "sangat baik", skor rata-rata dari ahli materi sebesar 92\% dengan kategori "sangat baik", dan skor rata-rata dari ahli soal materi sebesar 99,5\%. Sedangkan hasil uji kepraktisan diperoleh berdasarkan penilaian respon guru dan siswa dengan skor rata-rata respon guru sebesar 81,7\% dengan kategori "sangat baik" dan skor rata-rata respon siswa sebesar 92,82\% dengan kategori "sangat baik". Hasil penelitian menunjukkan bahwa siswa menyukai penggunaan media tongkat ajaib untuk mempermudah memahami materi dan dapat digunakan guru sebagai media alternatif mengajar. Kesimpulannya bahwa media tongkat ajaib valid dan praktis digunakan untuk siswa kelas IV sekolah dasar. Berdasarkan hasil penelitian ini saran yang dapat disampaikan adalah media tongkat ajaib dapat digunakan sebagai penyempurna penelitian dan sebagai salah satu alternatif guru dalam mengajar.
\end{abstract}

\section{PENDAHULUAN}

Pendidikan adalah proses perubahan tingkah laku, penambahan ilmu pengetahuan dan pengalaman hidup agar peserta didik menjadi lebih dewasa dalam pemikiran dan sikap. Pendidikan di era digital saat ini sangatlah pesat, kemajuan dalam bidang teknologi tidak hanya dinikmati oleh orang dewasa saja, anak-anak usia sekolah dasar juga sudah bisa menikmati dari hasil perkembangan teknologi saat ini. Teknologi banyak dimanfaatkan dalam dunia pendidikan, sebagai sarana dan prasarana interaksi antara pendidik dan peserta didik. Perkembangan teknologi saat ini mempunyai dampak positif dan damapak negatif, sebaiknya dampak positif lebih dominan dimanfaatkan oleh pengguna teknologi. Munculnya banyak kasus yang destruktif dalam konteks kebangsaan, misalnya terjadinya sentimen antar etnis, perselisihan antar suku, kasus-kasus narkoba, tawuran antar pelajar, kekerasan terhadap anak, begal di mana-mana, kasus Bullying, menunjukkan karakter kebangsaan yang lemah. Pembentukan karakter sedari dini akan menumbuhkan budaya karakter bangsa yang baik dan kunci utama dalam membangun bangsa. Pendidikan karakter bertujuan agar peserta didik sebagai penerus bangsa mempunyai akhak dan moral yang baik, untuk menciptakan kehiupan berbangsan yang adil, aman dan makmur. Tujuan Pendidikan dalam UndangUndang Nomor 20 tahun 2003 tentang Sistem Pendidikan

* Corresponding author.

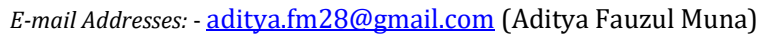


Nasional yang menyebutkan bahwa "Pendidikan nasional berfungsi mengembangkan kemampuan dan membentuk watak serta peradaban bangsa yang bermartabat dalam rangka mencerdaskan kehidupan bangsa, bertujuan untuk berkembangnya potensi peserta didik agar menjadi manusia yang beriman dan bertaqwa kepada Tuhan Yang Maha Esa, berakhlak mulia, sehat, berilmu, cakap, kreatif, mandiri dan menjadi warga negara yang demokratis serta bertanggung jawab (Palupi, 2018).

Menurut Munadi (2013: 5) media pembelajaran adalah sumber-sumber belajar selain guru sebagai penyalur atau penghubung pesan ajar yang diadakan dan atau diciptakan secara terencana oleh para guru atau pendidik. Menurut Munadhi media pembelajaran dibagi menjadi 4, yaitu; media audio, media visual, media audio visual, dan multimedia. Media audio adalah media yang bias didengar melalui indera pendengaran. Media visual adalah media yang melibatkan indera penglihatan. Media audio visual adalah media yang dapat didengar dan dilihat secara bersamaan. Dan multimedia adalah media sebagai bahasa atau multibahasa yakni ada bahasa yang mudah diapahami oleh indera pendengaran, penglihatan, penciuman, peraba dan lain sebagainya.

Berdasarkan posisinya sebagai penghubung disatu sisi dan sebagai peran penggiat disisi lain dan mempertimbangkan sering terjadinya komunikasi yang kurang atau tidak efektif, hendaknya guru berusaha untuk melakukan usaha-usaha tercapainya tujuan dalam komunikasi tersebut, diantaranya adalah dengan menyediakan media lain yang bias dijadikan sumber belajar oleh siswa. Berdasarkan uaraian tersebut maka dapat disimpulkan media pembelajaran dapat dipahami sebagai "Segala sesuatu yang dapat menyampaikan dan menyalurkan pesan dari sumber secara terencana sehingga tercipta lingkungan belajar yang kondusif di mana penerimanya dapat melakukan proses belajar secara efisien dan efektif". ( Munadi 2013: 7).

Media apabila dipahami secara garis besar adalah manusia, materi, atau kejadian yang membangun kondisi yang membuat mampu memperoleh pengetahuan, ketrampilan, atau sikap hal ini diungkapkan Arsyad (2006: 3). Kata media berasal dari bahasa latin dan merupakan bentuk jamak dari kata medium yang secara harifah berarti perantara atau pengantar.

Media pembelajaran sangat berperan penting dalam mendukung terjadinya suatu proses belajar mengajar didalam satu sekolah, seperti yang tertuang dalam Menurut Peraturan Pemerintah Republik Indonesia Nomor 19 Tahun 2005 tentang Standar Nasional Pendidikan BAB VII Standar Sarana dan Prasarana Pasal 24 ayat (1) yang menyatakan bahwa "Setiap satuan pendidikan wajib memiliki sarana yang meliputi perabot, peralatan pendidikan, media pendidikan, buku dan sumber belajar lainnya, bahan habis pakai, serta perlengkapan lain yang diperlukan untuk menunjang proses pembelajaran yang teratur dan berkelanjutan". Berdasarkan peraturan tersebut, maka media pembelajaran sangat diperlukan dalam menunjang proses pembelajaran yang teratur dan berkelanjut.

Pembelajaran di Sekolah Dasar, media pembelajaran dapat diterapkan dalam berbagai kurikulum seperti kurikulum 2013. Dalam Kamus Besar Bahasa Indonesia (1990:4479), diterangkan bahwa kata kurikulum merupakan kata benda yang memiliki dua arti. Pertama, perangkat mata pelajaran yang diajarkan pada lembaga pendidikan, dan kedua perangkat mata kuliah mengenai bidang keahlian khusus. Pada bagian lain Mulyasa (2009: 46) mengemukakan bahwa kurikulum merupakan rancangan dan pengaturan mengenai tujuan, kompetensi dasar, materi standar,dan hasil belajar, serta cara yang digunakan sebagai pedoman penyelenggaraan kegiatan pembelajaran untuk mencapai kompetensi dasar dan tujuan pendidikan. Jadi, dapat di simpulkan hakikat Kurikulum adalah seperangkat rancangan pelaksanaan pembelajaran untuk mencapai tujuannya.

Locust (2007: 209) mengemukakan pendapatnya. Tongkat berbicara telah digunakan selama berabad-abad oleh suku-suku Indian sebagai alat menyimak secara adil dan tidak memihak. Tongkat berbicara sering digunakan kalangan dewan untuk memutuskansiapa yang mempunyai hak berbicara. Pada saat pimpinan rapat mulai berdiskusi dan membahas masalah, ia harus memegang tongkat berbicara.Tongkat akan pindah ke orang lain apabila ia ingin berbicara atau menanggapinya. Dengan cara ini tongkat berbicara akan berpindah dari satu orang ke orang lain jika orang tersebut ingin mengemukakan pendapatnya. Apabila semua mendapatkan giliran berbicara, tongkat itu lalu dikembalikan lagi ke ketua/pimpinan rapat. Dari penjelasan Carol Locus (2007: 209) dapat di simpulkan bahwa Talking Stick dipakai sebagai tanda seseorang mempunyai hak suara (berbicara) yang diberikan secara bergiliran/bergantian.

Dari hasil analisis menyebar angket pada tanggal 15 Oktober 2018, diketahui bahwa hanya menggunakan media tongkat kayu sebagai media berbantu model Talking Stick. Padahal tongkat kayu biasa masih terdapat banyak kekurangannya. Seperti yang mendapat bagian memegang kayu, guru bertugas membacakan soal-soal. Hal ini belum efektif didalam sebuah pembelajaran dan bermain, karena dapat mengurangi waktu dalam pembelajaran. Untuk mengatasi masalah tersebut, perlu adanya media pembelajaran yang efektif dan efisien waktu dalam pembelajaran. Media hendaknya dapat membantu guru dan siswa dalam proses pembelajaran. Salah satu yang sesuai dengan kriteria diatas adalah Media 
Pembelajaran Tongkat Ajaib. Mengingat pentingnya media pembelajaran, peneliti ingin mengembangkan pembelajaran media Tongkat Ajaib yang dikemas di dalamnya terdapat soal pertanyaan dari materi yang sedang dipelajari.

Media Tongkat Ajaib, berbentuk tongkat yang berbahan resin fiberglass dapat dibuka dan ditutup, yang di dalamnya terdapat soal-soal dari materi Tema Peduli Terhadap Makhluk Hidup. Siswa dapat mengambil soal sendiri, karena Tongkat Ajaib terdapat 1-10 soal pertanyaan yang dapat membentuk karakter siswa mandiri dan rasa ingin tahu yang tinggi. Tongkat Ajaib ini bukan guru yang membecakan soal melainkan siswa yang mengambil dan membaca soal serta menjawab dari soal tersebut.

Berdasarkan hasil observasi dan menyebar angket kepada Bapak/Ibu Guru serta siswa dilakukan pada tanggal 25 Oktober 2018 ke 3 Sekolah Dasar yang mencakup di Daerah Kecamatan Mayong Kabupaten Jepara dengan menggunakan 30 s.d 100 subjek. SD Negeri 2 Pelemkerep dengan Ibu Guru Intanh Putri Widayanti dan jumlah siswa 21, SD Negeri 1 Mayong Lor dengan Ibu Guru Siti Sutikat dan jumlah siswa 18 dan di SDIT Alhusna Pelemkerep dengan Ibu Guru Iriyus Irianti dan jumlah siswa 23. Menunjukkan bahwa masih ada peserta didik yang masih kurang faham mengenai pembelajaran Kurikulum 2013 serta kurangnya media pembelajaran yang memadai untuk membantu proses belajar mengajar. Hal ini menyebabkan peserta didik kurang minat pembelajaran Kurikulum 2013 dan kurang mengetahui apa itu media pembelajaran.

Pembelajaran di Sekolah Dasar, media pembelajaran dapat diterapkan dalam berbagai kurikulum seperti kurikulum 2013. Dalam Kamus Besar Bahasa Indonesia (1990:4479), diterangkan bahwa kata kurikulum merupakan kata benda yang memiliki dua arti. Pertama, perangkat mata pelajaran yang diajarkan pada lembaga pendidikan, dan kedua perangkat mata kuliah mengenai bidang keahlian khusus. Pada bagian lain Mulyasa (2009: 46) mengemukakan bahwa kurikulum merupakan rancangan dan pengaturan mengenai tujuan, kompetensi dasar, materi standar,dan hasil belajar, serta cara yang digunakan sebagai pedoman penyelenggaraan kegiatan pembelajaran untuk mencapai kompetensi dasar dan tujuan pendidikan. Jadi, dapat di simpulkan hakikat Kurikulum adalah seperangkat rancangan pelaksanaan pembelajaran untuk mencapai tujuannya.

Mulyasa (2016: 65) mengatakan bahwa tujuan pengembangan Kurikulum 2013 kita akan menghasilkan insan Indonesia yang; produktif, kratif, inovatif, afektif, melalui penguatan sikap, ketrampilan, dan pengetahuan yang terintegrasi. Dalam hal ini, pengembangan kurikulum difokuskan pada pembentukan kompetensi dan karakter peserta didik, berupa paduan pengetahuan, ketrampilan pengetahuan, ketrampilan dan sikap yang dapat didemonstrasikan peserta didik sebagai wujud pemahaman terhadap konsep yang dipelajarinya secara kontekstual.

Guru menjadi faktor yang menentukan mutu pendidikan karena guru berhadapan langsung dengan para peserta didik dalam proses pembelajaran di kelas. Di tangan guru, mutu dan kepribadian peserta didik dibentuk. Karena itu, perlu sosok guru kompeten, bertanggung jawab, terampil, dan berdedikasi tinggi. Guru adalah kurikulum berjalan. Sebaik apa kurikulum dan sistem pendidikan yang ada tanpa didukung oleh kemampuan guru, semuanya akan sia-sia. Guru berkompeten dan bertanggung jawab, utamanya dalam mengawal perkembangan peserta didik sampai ke suatu titik maksimal. Tujuan akhir seluruh proses pendampingan guru adalah tumbuhnya pribadi dewasa yang utuh (Shabir, 2015).

Dari pendapat diatas, penulis menyimpulkan bahwa tujuan dari Kurikulum 2013 adalah dapat menghasilkan insan Indonesia yang produktif, keratif, inovatif, efektif, melalui sikap, ketrampilan dan pengetahuan untuk membentuk peserta didik paham akan konsep yang dipelajarinya.

Pendidikan merupakan program pemerintah yang wajib didapatkan oleh semua generasi penerus bangsa. Pendidikan nasional berfungsi mengembangkan kemampuan dan membentuk watak serta peradaban bangsa yang bermartabat dalam rangka mencerdaskan kehidupan bangsa. Untuk itu, pendidikan nasional bertujuan untuk mengembangkan potensi peserta didik agar menjadi manusia yang beriman dan bertaqwa pada Tuhan Yang Maha Esa, berakhlak mulia, sehat, berilmu, cakap, kreatif, mandiri dan menjadi warga negara yang demokratis serta bertanggung jawab (Undang-Undang No. 20 Tahun 2003).

Maka diadakan perubahan Kurikulum dengan tujuan untuk "Melanjutkan Pengembangan Kompetensi yang telah dirintis pada tahun 2004 dengan mencakup kompetensi sikap, pengetahuan, dan ketrampilan secara terpadu". Dari tujuan Kurikulum tersebut maka dapat diartikan bahwa tujuan kurikulum adalah untuk mencakup kompetensi pengetahuan, dan ketrampilan secara terpadu.

Berdasarkan latar belakang di atas maka peneliti tertarik untuk melakukan penelitian dengan jenis penelitian dan pengembangan (Research and Development). Alasan peneliti menggunakan jenis penelitian tersebut karena peneliti ingin memberikan variasi dalam pembelajaran yang berlangsung dengan mengembangankan sebuah media pembelajaran. Peneliti melakukan penelitian dengan judul "Pengembangan Media Tongkat Ajaib Pada Model Pembelajaran Talking Stick Tema Peduli Terhadap Makhluk Hidup Kelas IV Di SD Kecamatan Mayong Kabupaten Jepara “. Dengan judul tersebut diharapkan 
dapat membantu guru memberikan inovasi dan kreativitas belajar mengajar serta menciptakan ketertarikan peserta didik dalam pembelajaran.

\section{METODE PENELITIAN}

Dalam penelitian ini, metode yang dikembangkan adalah jenis metode Penelitian dan Pengembangan atau Research and Development (R\&D). Menurut buku Sugiyono (2017: 477) mengartikan, Penelitian dan Pengembangan atau Research and Development (R\&D) adalah cara ilmiah untuk meneliti, merancang, memproduksi dan menguji validitas produk yang telah dihasilkan. Berdasarkan penelitian tersebut, kegiatan penelitian dan pengembangan dapat disingkat menjadi 4P (Penelitian, Perancangan, Produksi, dan Pengujian), dalam hal ini produk dapat berupa kebijakan.

Dari pengertian diatas, dapat disimpulkan bahwa metode Penelitian dan Pengembangan atau Research and Development ( $R \& D$ ) adalah suatu penelitian untuk memproduksi produk kemudian menguji validitas produk tersebut. Produk yang dihasilkan diuji berupa keefektifan media pembelajaran, model pembelajaran dan materi pembelajaran.

Menurut buku Sugiyono (2017: 2) cetakan terbaru bulan September 2107, mengartikan Metode Penelitian dan Pengembangan (Research and Development) adalah secara umum metode penelitian diartikan cara ilmiah untuk mendapatkan data dengan tujuan dan kegunaan tertentu. Cara ilmiah berarti kegiatan penelitian itu didasarkan pada ciri-ciri keilmuan ( rasional, empiris, dan sistematis). Rasional berarti kegiatan penelitian dilakukan dengan cara-cara yang masuk akal, sehingga terjangkau oleh penalaran manusia. Empiris berarti cara-cara itu dapat diamati oleh indera manusia, sehingga orang lain dapat mengamati dan mengetahui. Sistematis berarti penelitian itu menggunakan langkah-langkah tertentu yang bersifat logis.

Berdasarkan uraian diatas, maka dapat diartikan bahwa Penelitian dan Pengembangan ( Research and Development) adalah kegiatan berdasarkan keilmuan yang dilakukan secara masuk akal sehingga dapat diamati oleh indera manusia yang penelitiannya menggunakan langkah-langkah tertentu yang bersifat logis.

Penelitian dan Pengembangan Research and Development (R\&D) dipilih karena peneliti mengembangkan produk yang berupa media pembelajaran Tongkat Ajaib pada Model pembelajaran Talking Stick hal ini merupakan media yang inofatif bagi guru dan siswa yang melalui dengan tahap pengujian (validitas produk) terlebih dahulu. Media pembelajaran Tongkat Ajaib ini fiberglass yang berupa tongkat di dalamnya terdapat soal-soal materi dari Tema Peduli Terhadap Makhluk Hidup.

\section{ANALISIS DAN PEMBAHASAN}

Penelitian Media pembelajaran tongkat ajaib dikembangkan peneliti berdasarkan langkah-langkah penelitian dan pengembangan (research and development). Peneliti menggunakan desain pengembangan yang dikemukakan Sugiyono (2017 : 501), yaitu : (1) Potensi dan Masalah, (2) Studi Literature/Pengumpulan Informasi, (3) Rancangan Produk, (4) Validasi Desain, (5) Revisi Desain, (6) Pembuatan Produk, (7) Uji Coba Terbatas, (8) Revisi Produk 1, (9) Uji Coba Lapangan Utama, (10) Revisi Produk 2, (11) Uji Coba Lapangan Oprasional, (12) Revisi Produk 3, (13) Desiminsi dan Implementasi. Dari tiga belas (13) langkah tersebut, peneliti mengambil tujuh langkah dalam proses ini yakni hanya sebatas pada merevisi produk yang kemudian dimodifikasi oleh peneliti menjadi beberapa tahapan yaitu:

1. Potensi dan Masalah

Peneliti mencoba mencari kemampuan yang dimiliki oleh siswa dan guru. Kemudian peneliti juga mencari permasalahan-permasalahan yang timbul ketika pembelajaran berlangsung sehingga mengakibatkan terhambatnya pembelajaran yang aktif, efektif dan menyenangkan.

2. Pengumpulan Informasi

Peneliti menemukan potensi dan masalah yang diambil dari obserfasi dan hasil angket kebutuhan siswa dan guru di kelas IV di SD Negeri Mayong Lor 1, SD Negeri 2 Pelemkerep dan SDIT Al-Husna Pelemkerep untuk mengetahui permasalahan yang ada dan untuk mengetahui pemecahan dari masalah tersebut yaitu dengan menggunakan media pembelajaran tongkat ajaib.

3. Desain Produk

Peneliti memulai pembuatan media pembelajaran tongkat ajaib dengan membuat konsep terlebih dahulu. Setelah konsep jadi, peneliti melanjutkan mendesain konsep tersebut, lau peneliti membuat tongkat dari bahan fiber glass yang dicetak menggunakan setengah pralon yang telah di olesi MAA suapay saat fiber glass kering cetakan dapat di ambil. Setelah hasil tongkat fiber glass jadi, maka tongkat di amplas menggunakan amplas kasar sambil di rendam air terlebih dahulu, setelah halus maka tahap selanjutnya adalah menggrenda agar hasilnya lebih bening dan transparan. Tongkat ajaib 
bahan fiberglass kemudian di beri lubang bagian samping unuk tempat kawat saat diberi di dalamnya. Peneliti memberikan tambahan lampu led warna-warni agar tampilan saat belajar dan bermain menjadi lebih menarik dan berwarna, tidak lupa dengan memberikan skakel suapaya ketika tidak di pergunakan batrai lampu led tidak cepat habis.

4. Validasi Desain

Peneliti melakukan validasi desain dengan menggunakan media tongkat ajaib pada ahli media, ahli materi dan ahli soal materi dengan membagikan angket validasi ahli media, ahli materi dan ahli soal materi untuk mengetahui tingkat kevalidan media tongkat ajaib. Berikut adalah penjelasannya:

a. Hasil Validasi Ahli Media

Tahap validasi ahli media bertujuan untuk mengetahui kelayakan pembuatan produk media pembelajaran tongkat ajaib sebelum dilakukan uji coba lapanga awal. Pada tahap ini, peneliti memilih satu validator sebagai validator ahli media yang merupakan dosen Pendidikan Guru Sekolah Dasar Universitas PGRI Semarang yaitu bapak Rofian S.Pd., M.Pd. Validasi media dilakukan dengan memberikan lembar angket validasi ahli media. Berikut adalah hasil analisis penliaian dari ahli media tahap pertama pada Tabel 1.

Tabel 1. Hasil Validasi Ahli Media Tahap 1

\begin{tabular}{cccc}
\hline No & Ahli Media & Presentasi Keidealan & Kriteria \\
\hline 1. & Rofian S.Pd., M.Pd & $66,7 \%$ & Cukup \\
\hline
\end{tabular}

Berdasarkan Tabel 1. Maka dapat diperoleh hasil rata-rata presentase keidealan penilaian ahli media tahap pertama sebesar $66,7 \%$ sehingga media tongkat ajaib termasuk dalam kriteria "cukup". Namun, peneliti masih melakukan validasi tahap kedua untuk memperbaiki produk.

Setelah melakukan perbaikan yang telah disarankan oleh ahli media seperti memperbaiki cover, memberikan petunjuk pemakaian media tongkat ajaib, memberikan tema 3 peduli terhadap makhluk hidup. Berikut adalah hasil analisis penilaian ahli media tahap kedua pada Tabel 2. Sebagai berikut :

Tabel 2. Hasil Validasi Ahli Media Tahap 2

\begin{tabular}{cccc}
\hline No & Ahli Media & Presentasi Keidealan & Kriteria \\
\hline 1. & Rofian S.Pd., M.Pd & $99 \%$ & Sangat Baik \\
\hline
\end{tabular}

Berdasarkan Tabel 2 Maka dapat diperoleh hasil rata-rata presentase keidealan penilaian ahli media tahap pertama sebesar 99\% sehingga media tongkat ajaib termasuk dalam kriteria "Sangat Baik" dan dapat di pergunakan di lapangan.

Hasil Validasi Ahli Materi Tahap validasi ahli materi bertujuan untuk mengetahui kelayakan materi dalam media pembelajaran tongkat ajaib sebelum dilakukan uji coba lapanga awal. Pada tahap ini, peneliti memilih satu validator sebagai validator ahli materi yang merupakan dosen Pendidikan Guru Sekolah Dasar Universitas PGRI Semarang yaitu bapak M. Yusuf Setai W. S.Pd., M.Pd. Validasi media dilakukan dengan memberikan lembar angket validasi ahli materi. Berikut adalah hasil analisis penliaian dari ahli materi tahap pertama pada Tabel 3 Sebagai berikut :

Tabel 3. Hasil Validasi Ahli Materi Tahap 1

\begin{tabular}{cccc}
\hline No & Ahli Media & Presentasi Keidealan & Kriteria \\
\hline 1. & M. Yusuf Setia W. S.Pd., M.Pd & $92 \%$ & Sangat Baik \\
\hline
\end{tabular}

Berdasarkan Tabel 3. Maka dapat diperoleh hasil rata-rata presentase keidealan penilaian ahli materi tahap pertama sebesar 92\% sehingga media tongkat ajaib termasuk dalam kriteria "Sangat Baik" dan di berikan catatan oleh bapak M. Yusuf Seta W. S.Pd,. M.Pd yaitu berupa perbaikan huruf dan disesuaikan dengan KD \& Indikator kemudian dapat di pergunakan di lapangan.

Hasil Validasi Ahli Soal Materi Tahap validasi ahli soal materi bertujuan untuk mengetahui kelayakan soal materi dalam media pembelajaran tongkat ajaib sebelum dilakukan uji coba lapanga awal. Pada tahap ini, peneliti memilih satu validator sebagai validator ahli materi yang merupakan dosen Pendidikan Guru Sekolah Dasar Universitas PGRI Semarang yaitu bapak Asep Ardiyanto S.Pd., M.Or. Validasi soal materi dilakukan dengan memberikan lembar angket validasi ahli soal materi. Berikut adalah hasil analisis penliaian dari ahli soal materi tahap pertama pada Tabel 4 Sebagai berikut : 
Tabel 4. Hasil Validasi Ahli Soal Materi Tahap 1

\begin{tabular}{|c|c|c|c|}
\hline No & Ahli Media & Presentasi Keidealan & Kriteria \\
\hline 1. & Asep Ardiyanto S.Pd., M.Or. & $62,5 \%$ & Cukup \\
\hline
\end{tabular}

Berdasarkan Tabel 4 Maka dapat diperoleh hasil rata-rata presentase keidealan penilaian ahli soal materi tahap pertama sebesar 62,5\% sehingga media tongkat ajaib termasuk dalam kriteria "Cukup" dan dapat digunakan dengan revisi.

Setelah melakukan perbaikan yang telah disarankan oleh ahli soal materi seperti memperbaiki tata bahasa, menambahkan 2 soal di dalam 10 soal materi, dan menyesuaikan dengan KD \& Indikator. Berikut adalah hasil analisis penilaian ahli media tahap kedua pada Tabel 5 Sebagai berikut :

Tabel 5. Hasil Validasi Ahli Soal Materi Tahap 2

\begin{tabular}{llll}
\hline No & Ahli Media & Presentasi Keidealan & Kriteria \\
\hline 1. & Asep Ardiyanto S.Pd., M.Or. & $99,5 \%$ & Sangat Baik \\
\hline
\end{tabular}

Berdasarkan Tabel 5 Maka dapat diperoleh hasil rata-rata presentase keidealan penilaian ahli materi tahap pertama sebesar 99,5\% sehingga soal materi tongkat ajaib termasuk dalam kriteria "Sangat Baik" dan dapat digunakan dilapangan.

5. Perbaikan Desain

Perbaikan desain yang di lakukan oleh peneliti, langkah-langkahnya hampis sama dengan langkah pembuatan produk. Peneliti hanya menambahkan sesuai arahan dan revisi dari validator ahli media yaitu menambahkan bagian luarnya, peneliti memberikan pralon yang diameternya lebih besar dari tongkat yang di dalamnya, pralon di potong sesuai ukuran tongkat fiber glass, kemudian pralon di beri stiker judul tongkat ajaib, stiker tema 3 peduli terhadap makhluk hidup, dan stiker petunjuk pemakaian tongkat ajaib. Kemudian tongkat ajaib diberikan tutup supaya tongkat fiber glass dan materi di dalam tongkat ajaib tidak terjatuh.

6. Uji Coba Produk

Peneliti melakukan uji coba produk dengan menggunakan media tongkat ajaib pada pembelajarannya dan membagikan lembar angket respon siswa dan guru kelas IV untuk mengetahui tingkat kepraktisan media Tongkat ajaib Berikut adalah penjelasannya:

a. Hasil Respon Siswa

Media pembelajaran tongkat ajaib adalah susatu hal yang baru bagi siswa. Hasil angket respon siswa bertujuan untuk mengetahui respon siswa terhadap keberterimaan media pembelajaran tongkat ajaib pada uji coba lapangan awal dengan dilakukan pengisian angket respon siswa kelas IV di tiga sekolah yaitu di SD Negeri Mayong Lor 1, SD Negeri 2 Pelemkerep, dan SDIT Al-Husna Pelemkerep dan di peroleh dengan hasil sebagai berikut :

Tabel 6. Hasil Siswa

\begin{tabular}{cccc}
\hline No & Ahli Media & Presentasi Keidealan & Kriteria \\
\hline 1. & SD Negeri Mayong Lor 1 & $90 \%$ & Sangat Baik \\
\hline 2. & SD Negeri 2 Pelemkerep & $91,4 \%$ & Sangat Baik \\
\hline 3. & SDIT Al-Husna Pelemkerep & $93,5 \%$ & Sangat Baik \\
\hline
\end{tabular}

Berdasarkan Tabel 6 Maka dapat diperoleh hasil rata-rata presentase keidealan penilaian respon siswa sebesar 92,82\% sehingga media tongkat ajaib ermasuk dalam kriteria "sangat baik".

Hasil Respon Guru Hasil angket respon guru kelas bertujuan untuk mengetahui respon guru kelas terhadap kelayakan media tongkat ajaib pada uji coba lapangan awal dengan dilakukan pengisian angket respon guru kelas IV di tiga sekolah yaitu di SD Negeri Mayong Lor 1, SD Negeri 2 Pelemkerep, dan SDIT Al-Husna Pelemkerep serta diperoleh hasil sebagai berikut : 
Tabel 7. Hasil Guru

\begin{tabular}{cccc}
\hline No & Ahli Media & Presentasi Keidealan & Kriteria \\
\hline 1. & SD Negeri Mayong Lor 1 & $75 \%$ & Baik \\
\hline 2. & SD Negeri 2 Pelemkerep & $80 \%$ & Sangat Baik \\
\hline 3. & SDIT Al-Husna Pelemkerep & $90 \%$ & Sangat Baik \\
\hline
\end{tabular}

Berdasarkan Tabel 7 Maka dapat diperoleh hasil rata-rata presentase keidealan penilaian respon siswa sebesar $81,7 \%$ sehingga media tongkat ajaib ermasuk dalam kriteria "sangat baik". Revisi produk tidak diperlukan oleh peneliti karena dalam uji coba produk, produk dikatakan praktis, valid dan tidak memerlukan revisi lagi. Produk Siap Media pembelajaran tongkat ajaib telah siap dan dapat digunakan menjadi media alternative ketika mengajar yang dapat membantu peserta

\section{KESIMPULAN}

Berdasarkan Hasil penelitian dan pengembangan media oleh peneliti yaitu media tongkat ajaib valid digunakan pada tema 3 peduli terhadap makhluk hidup kelas IV pada tiga sekolah dasar yaitu di SD Negeri Mayong Lor 1, SD Negeri 2 Pelemkerep, dan SDIT Al-Husna Pelemkerep dengan mendapat skor rata-rata presentase keidealan dari ahli media sebesar $99 \%$ dengan kriteria "sangat baik", dari skor ratarata presentase keidealan ahli materi sebesar 92\% dengan kriteria "sangat baik" dan dari skor rata-rata keidealan ahli soal materi sebesar 97,5\% dengan kriteria "sangat baik".

Media pembelajaran tongkat ajaib praktis digunakan pada tema 3 peduli terhadap makhluk hidup kelas IV pada tiga sekolah dasar yaitu di SD Negeri Mayong Lor 1, SD Negeri 2 Pelemkerep, dan SDIT AlHusna Pelemkerep dengan mendapat skor rata-rata presentase keidealan hasil respon guru sebesar 81,7\% dengan kriteria "sangat baik" dan dari skor rata-rata presentase keidealan hasil respon siswa sebesar 92,82\% dengan kriteria "sangat baik". Hal ini dapat dilihat bahwa media tongkat ajaib dapat mempermudah siswa dalam memahami materi karena penggunaan media yang mudah, materi yang sesuai dengan tema 3 peduli terhadap makhluk hidup yang dibuat dengan jelas dan menarik. Selain itu, media tongkat ajaib juga dapat digunakan sebagai media alternatif guru dalam mengajar tematik karena guru tidak perlu memerlukan banyak waktu untuk mengajar tematik dan membuat media setiap mata pelajarannya.

Berdasarkan simpulan diatas adapun saran yang diberikan peneliti sebagai berikut: 1) Bagi Guru, penggunaan media dalam pembelajaran dapat digunakan oleh guru untuk meningkatkan tingkat kefokusan siswa pada pembelajaran sehingga siswa menjadi senang dan antusias mengikuti pembelajaran serta dapat mengefektifkan waktu supaya tidak membutuhkan waktu yang lama dalam mengajar tematik, 2) Bagi Sekolah, pihak sekolah sebaiknya memberi fasilitas terhadap guru yang memiliki kreativitas dalam mengembangkan sebuah media pembelajaran untuk menunjang kebutuhan siswa dalam pembelajaran, 3) Bagi Peneliti, peneliti menyadari bahwa penelitian dan pengembangan ini belum sempurna, maka diharapkan dilakukan penelitian pengembangan selanjutnya di kemudian hari guna menyempurnakan penelitian ini dan menjadi produk baru dalam penelitian pengembangan tentang media pembelajaran.

\section{DAFTAR PUSTAKA}

Arikunto, Suharsimi. 2007. Manajemen Penelitian. Jakarta: Rineka Cipta.

Charitas Indra Prahmana, Rully. 2017. Design Research: (Teori dan Implementasinya: Suatu Pengantar). Yogyakarta: Rajawali Pers.

Danim S. 2013. Perkembangan Peserta Didik. Bandung: Alfabeta, cv

Dewi, Lina Rusmala. 2017. Keefektifan Model Pembelajaran Snowball Throwing Berbantu Media Tongkat Simulasi (Tongsis)Terhadap Hasil Belajar Matematika Siswa Kelas II SDN Candi 01 Semarang. Skripsi. Di terbitkan. Fakultas Ilmu Pendidikan Universitas PGRI Semarang: Semarang.

Huda, Miftahul. 2017. Model-model Pengajaran dan Pembelajaran. Malang: Pustaka Pelajar.

Hastuti, Endang Sri. 2014. Keefektifan Metode Tongkat Berjalan (Talking Stick) Dalam Pembelajaran Menulis Surat Pribadi Siswa Kelas VII MTS Miftahul Ulum Karangrejo Bonang Demak Tahun Ajaran 2014/2015. Di terbitkan. Fakultas Ilmu Pendidikan Universitas PGRI Semarang: Semarang. 
Munadi, Yudhi. 2013. Media Pembelajaran (Sebuah Pendekatan Baru). Jakarta: Referensi.

Mauli, Geri Valdi. 2018. Keefektifan Metode Tongkat Berestafet Dalam Menceritakan Tokoh Idola Pada Pembelajaran Berbicara. Jurnal. Di terbitkan Fakultas Pendidikan Bahasa dan Sastra Universitas Pendidikan Indonesia: Bandung.

Shabir, M. 2015. Kedudukan Guru Sebagai Pendidik . Jurnla Auladuna, Vol. 2 No. 2 Desember 2015: 221232

Sugiyono. 2017. Metode Penelitian Kebijakan. Yogyakarta: Alfabeta.

Sugiyono. 2017. Metode Penelitian \& Pengembangan (Research and Development). Yogyakarta: Alfabeta

Mulyasa. 2016. Pengembangan dan Implementasi Kurikulum 2013. Bandung: Rosda.

Shoimin, Aris. 2017. 68 Model Pembelajaran Inovatif dalam Kurikulum 2013. Rembang: Ar-Ruzz Media.

Suyitno, Mudzanatun, dan Anggun Dwi Setya P. 2017. Kajian Kurikulum Bahasa Indonesia Sekolah Dasar. Semarang: Universitas PGRI Semarang Pres.

Susanto Ahmad. 2016. Teori Belajar \& Pembelajaran di Sekolah Dasar. Jakarta: Prenadamedia Group.

Undang-undang Dasar Negara Republik Indonesia No.20 Tahun 2003 Pasal 1 ayat 1 tentang Sistem Pendidikan Nasional.

UPGRIS. 2015. Pedoman Bimbingan Penulisan \& Ujian Skripsi serta Penelitian Artikel Ilmiah. Semarang: UPGRIS.

Wahyuni, Sri \& I Nengah, Yusdin. 2018. Penerapan Metode Talking Stick Untuk Meningkatkan Hasil Belajar IPA Kelas IV Di SDN 2 Pesona. Jurnal. Di terbitkan. Fakultas Keguruan dan Ilmu Pendidikan Universitas Tadulako : Palu

Palupi, Dini. 2018. Pendidikan Karakter Pada Anak Sekolah Dasar di Era Digital . Jurnal Pendidikan Dasar vol. 2, no. 1, 2018 